\title{
Influence of increased doses of microelements in hydroponic nutrient solution on the yield of Capsicum annuum L. fruits and their capsaicin content
}

\section{TOMASZ JAN NOWAK}

Botanical Garden, Wrocław University, Wrocław*

(Received: November 8, 1977)

\begin{abstract}
The Wrocław version of hydroponic culture was applied. The content of particular microelements $(\mathrm{Cu}, \mathrm{B}, \mathrm{Mn}, \mathrm{Mo}, \mathrm{Zn})$ or several of them jointly was increased ten times (to $6 \mathrm{mg} / \mathrm{l}$ ) as compared to the standard composition of the nutrient solution. It was found that the yield of fruits and of capsaicin per plant was significantly higher with 10 times increased content of $\mathrm{Cu}$ and $\mathrm{B}$ or $\mathrm{Cu}+\mathrm{B}+\mathrm{M}$ o or $\mathrm{Cu}+\mathrm{Mn}+\mathrm{Mo}$ or $\mathrm{B}+\mathrm{Mn}+\mathrm{Mo}$. Moreover, $\mathrm{Cu}$ and $\mathrm{Mn}$ applied alone or in combinations with other microelements in 10-fold increased proportion caused a marked increase of capsaicin content in the dry matter of the fruit. It is suggested that the proportions of microelements should be chosen individually for each plant species and for each type of agroclimatic conditions
\end{abstract}

\section{INTRODUCTION}

Capsaicin obtained from the fruits of Capsicum annuum L. is a raw material used in the production of various drugs with a rather wide application (M uszyński, 1957). Owing to the compounds accompanying capsicin and similar in structure to it, as for instance dihydroxycapsaicin, homocapsaicin of homodihydroxcapsaicin (T y i h a k et al., 1966; Leete and Louden, 1968) as well as the presence in the fruit of a number of vitamins (Cholnoky, 1937; Śpaldon, 1948), the fruits of Capsicum are so far the only source of capsaicin for therepeutic purposes, although a synthetic capsaicin has been obtained.

The amount of capsaicin in Capsicum fruits is a varietal trait and may amount from 0.01 to 0.4 per cent ( $\mathrm{Sk}$ a p ski, 1955; B la im et al., 1957; Gertig and Olszak, 1957; Michna, 1968). It also de-

* Present address: Agro- and Hydrometeorological Department, Agriculture Academy of Wroclaw, Plac Grunwaldzki 24, 50-363 Wrocław. 
pends on the climatic conditions, for instance $\mathrm{Buchi}$ and $\mathrm{Hippen-}$ meier (quoted after Blaim et al., 1957) demonstrated that the amount of capsaicin increases in the fruits when the weather is dry and sunny. Accumulation of capsaicin may also be influenced by soil moisture, the season or the time of day ( $\mathrm{u}$ agliotti, 1971). Capsaicin content is also dependent on the degree of ripeness of the fruits (Borkowski et al., 1957a; Michna, 1966; Balba a et al., 1968) and of the method of their drying (B o r k ow s k i et al., 1957b).

In some few studies it was attempted to inarease the capsaicin amount in the fruits by fertilization. Ts chirch (quoted after $\mathrm{Cz}$ a$\mathrm{bajski}$ and $\mathrm{Załęcki,} \mathrm{1967)} \mathrm{mentions} \mathrm{that} \mathrm{the} \mathrm{capsaicin} \mathrm{level} \mathrm{is}$ favourably influenced by NP fertilization. This correlation, however, has not been confirmed by other authors ( $\mathrm{Czabajski}$ and $\mathrm{Z}$ a łęcki, 1967; G o l c z e t al., 1970).

The present study was undertaken to test the influence of quantitatively differentiated fertilization with microelements on the yield of Capsicum fruits and on their capsaicin content.

\section{METHODS}

The experiments were performed in a glesshouse from I 25 to October 6, 1974. The plants were grown in Wrocław version of hy-

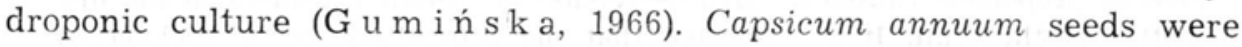
sown directly into the hydroponic matrix. A nutrient medium of routine composition and matrix described in another paper were used (N ow a k, 1980a), other methodical details are described in the same paper.

In the routine nutrient medium the amount of particular microelements was 10-fold increased ( $6 \mathrm{mg} / 1$ of the given compound) accordino to the scheme shown in Figure 1. At the beginning of the experiment $100 \mathrm{mg}$ of water-soluble sodium humate was added to the nutrient medium in each replication. In the course of the whole vegetation period each plant received $18 \mathrm{~g}$ mineral salts in the form of the basic medium, which was the optimal dose ( $\mathrm{N} \mathrm{ow} \mathrm{a} \mathrm{k,} \mathrm{1980b).}$

Tap water was used in the experiment containing microelements in the following quantities (mg/l): copper 0.03-0.035, boron 0.008-0.01, manganese 0.08-0.1, molybdenum 0.005-0.006, zinc 0.07-0.08.

Copper was determined by the colorimetric method with the use of diethyldithiocarbanate, zinc by the same method with the use of ditizone (Hermanowicz et al., 1967), boron by the carmine method, molybdenum by the rhodanate method (M a rczenko, 1968) and manganese by the colorimetric method with a silver catalyser (Gomółka and Szypowski, 1975). 
During the experiments protective agents against aphids were applied: Nogos GEC 50 and Mszycol. The experiments were run under the microcolimatic conditions described in Table 1.

The fresh weight of the fruits, dry weight of fruits, the per cent of mature fruits, capsaicin content in the fruits and its yield were determined.

$\mathrm{Tab} 1 \mathrm{e} 1$

Outdoor climatic conditions during the vegetation season

\begin{tabular}{lcccccc}
\hline Month & $\mathrm{t}\left({ }^{\circ} \mathrm{C}\right)$ & $\mathrm{t}_{\max }$ & $\mathrm{t}_{\min }$ & $\mathrm{t}<13^{\circ} \mathrm{C}$ & $\mathrm{r} . \mathrm{h} .(\%)$ & $\mathrm{S}(\mathrm{h})$ \\
\hline VI & 17.6 & 19.2 & 13.7 & 2 & 76 & 130.9 \\
VII & 18.2 & 21.3 & 14.8 & 0 & 79 & 131.1 \\
VIII & 21.2 & 25.6 & 16.9 & 0 & 86 & 181.3 \\
IX & 15.2 & 18.7 & 10.8 & 8 & 87 & 150.7 \\
$\begin{array}{l}\text { mean or } \\
\text { total }\end{array}$ & 17.7 & 21.0 & 13.9 & & 82 & \\
from 25 V to 6 X & & & & 13 & & 634.3 \\
\hline
\end{tabular}

Explanation of symbols: $t$-mean air temperature, $t_{\max }$-mean maximum air temperature, $t_{\min }-$ mean minimum air temperature, $\mathrm{t}<13^{\circ} \mathrm{C}$ - number of days and nights with mean air temperature $13^{\circ} \mathrm{C}, \mathrm{S}-$ insolution (in hours).

Within each combination (treatment) 6 replications were performed. One replication consisted of one plant growing in one jar. Statistical calculations (of fruit yield) were done by analysis of variance (U 1 in $\mathrm{s} \mathrm{ka}$, 1957). The significance of differences between all pairs of means was estimated by D uncan's multiple range test ( $\mathrm{W}$ a lle $\mathrm{r}$ and D uncan, 1969). As regards capsaicin content the error of the method of determination was calculated on homogeneous material.

\section{RESULTS}

In order to simplify the description of results, the notations $\mathrm{Cu}$, $\mathrm{B}, \mathrm{Mn}, \mathrm{Mo}$ and $\mathrm{Zn}$ will denote in the further text that these elements were present in the hydroponic solution in 10 -fold increased amounts $(6 \mathrm{mg} / \mathrm{l})$ of each, and the remaining substances in routine amounts (0.6 mg/l).

The methods of treatment of Capsicum annuum strongly influenced the fruit yield. The harvest of fresh fruit weight increased under the influence of $\mathrm{Cu}, \mathrm{B}$ and $\mathrm{Zn}$, whereas the remaining two microelements $\mathrm{Mn}$ and Mo reduced it (Fig. 1). When two microelements were used jointly, $\mathrm{Cu}$ with $\mathrm{B}$ increased the yield to a higher degree than $\mathrm{Cu}$ 


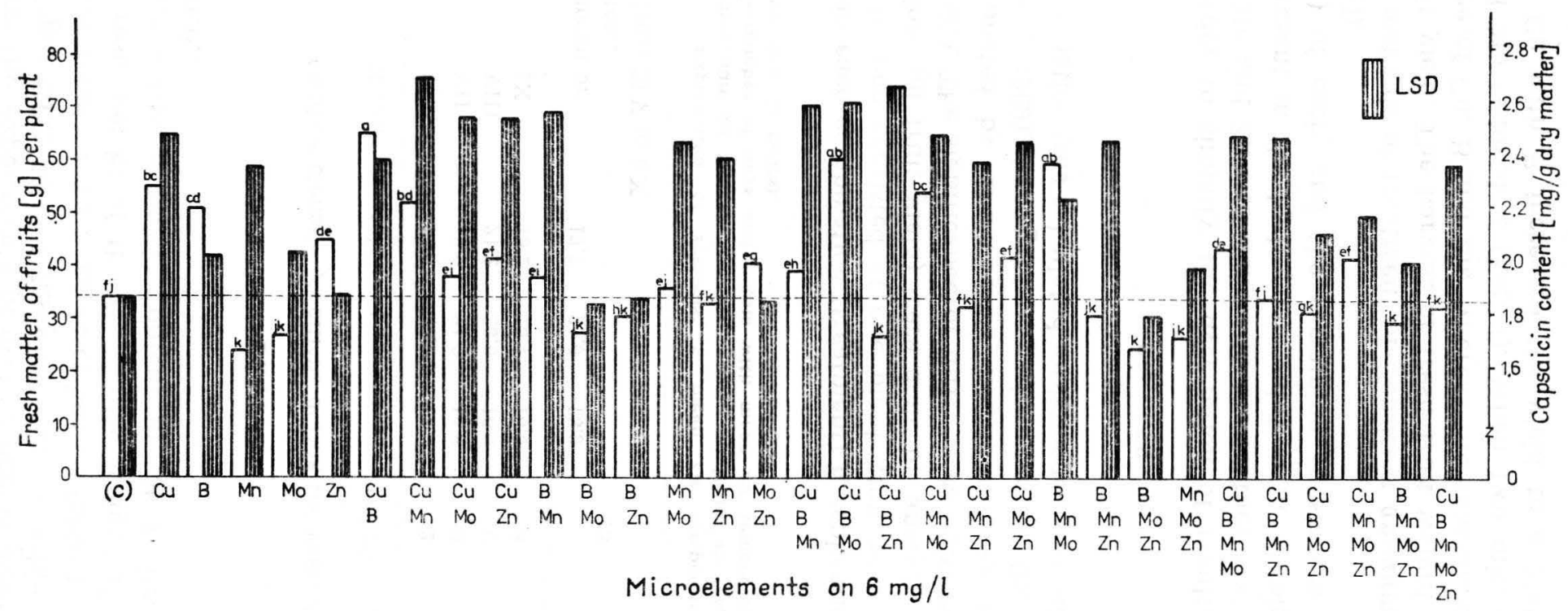

Fig. 1. The influence of 10 -fold increased amounts of particular microelements $(\mathrm{Cu}$, $\mathrm{B}, \mathrm{Mn}, \mathrm{Mo}, \mathrm{Zn}$ ) in hydroponic nutritive solution on the yield of fruits per plant and on the capsaicin content in dry matter of Capsicum annuum L. fruits

The symbol of a given microelement below a column means that it was given in the amount $6 \mathrm{mg} / \mathrm{l}$ whereas the all others were given in the amount 10 -fold lower; (c)-control 
alone (additive effect). The stimulating effect of $\mathrm{Cu}+\mathrm{Mn}$ was similar to that $\mathrm{cf} \mathrm{Cu}$ alone. In other combinations of two elements their action was not significant. In simultaneous application of 3 microelements only $\mathrm{Cu}+\mathrm{B}+\mathrm{Mo}, \mathrm{Cu}+\mathrm{Mn}+\mathrm{Mo}$ and $\mathrm{B}+\mathrm{Mn}+$ Mo markedly increased the fruit yield. The influence of these combinations was similar to that of $\mathrm{Cu}+\mathrm{B}$ and $\mathrm{Cu}$ alone. The combination $\mathrm{Cu}+\mathrm{Mo}+\mathrm{Zn}$ also showed a tendency to increasing the yield. $\mathrm{B}+\mathrm{Mo}+\mathrm{Zn}$ diminished the yield. Their action was similar to that of $\mathrm{Mn}$ alone. A reducing tendency was also observed when $\mathrm{Cu}+\mathrm{B}+\mathrm{Zn}, \mathrm{B}+\mathrm{Mn}+\mathrm{Zn}$ and $\mathrm{Mn}+\mathrm{Mo}+$ $\mathrm{Zn}$ were used. Increased amounts of 3 microelements in the remaining combinations were without effect. When 4 substances were applied simultaneously only $\mathrm{Cu}+\mathrm{B}+\mathrm{Mn}+\mathrm{Mo}$ increased the fruit yield. The remaining combinations as well as the application of the 5 microelements in a high dose had no influence.

Capsaicin content in the fruits (Fig. 1) depended strongly on the quantitative composition of microelements in the nutrient medium. $\mathrm{Cu}$ and $\mathrm{Mn}$ either alone or in combination with other microelements increased the capsaicin content in the fruits. An exception were the combinations: $\mathrm{Mn}+\mathrm{Mo}, \mathrm{Mn}+\mathrm{Zn}$ and $\mathrm{Mn}+\mathrm{B}+\mathrm{Mo}$ in which the stimulating action of $\mathrm{Mn}$ was not manifested. The remaining microelements (B, Mo and $\mathrm{Zn}$ ) had no influence either when singly added or jointly.

The dry weight content in fruits did not depend on the treatment with microelements and amounted from 14.77 to $16.1 \%$. The number of ripe fruits varied from 92 to $100 \%$. The capsaicin yield of one plant was 6.5 to $24.1 \mathrm{mg}$ and was the higher the larger was the fruit yield and the capsaicin content in them.

\section{DISCUSSION}

Treatment with increased amounts of microelements in the hydroponic nutrient solution $(6 \mathrm{mg}$ instead of $0.6 \mathrm{mg} / \mathrm{l})$ influenced the capsaicin yield indirectly by increasing the fruit yield and directly by increasing the capsaicin content in them.

The effect of increased amounts of microelements on the fresh weight of the fruits depended on the quantitative interrelations between all the microelements in the medium. When $\mathrm{Cu}, \mathrm{B}$ or $\mathrm{Zn}$ content was increased in the hydroponic solution, these proportions between the microelements stimulated the yield. Simultaneous increase of the amounts of $\mathrm{Cu}$ and $\mathrm{B}$ gave an additional stimulating effect, whereas simultaneously increased $\mathrm{B}$ and $\mathrm{Zn}$ amounts had no influence on the fruit yield although each of these elements used separately increased the yield.

These results confirm the numerous data indicating a positive in- 
fluence of microelements on the quantity and quality of the yield of a number of other plants (Sójkow ski, 1971). They show also necessity to establish optimal proportions between the microele. ments in the mixture for every plant species and for the given agroclimatic conditions.

The rise of capsaicin level in the fruits evoked by $\mathrm{Cu}$ or $\mathrm{Mn}$ may be explained by their indirect influence on biosynthesis of this substance. $\mathrm{Cu}$ and $\mathrm{Mn}$, namely, stimulate amino acid biosynthesis ( $\mathrm{S}$ ó jk ow ski, 1971), and some of the latter (phenylalanine, valine, methionine) may be precursors for capsaicinoids synthesis (Leete and L o u d e n, 1968).

It would seem that the dependence of the capsaicin level in the Capsicum annuum fruits on climatic conditions ( $\mathrm{H}$ as enbusch, 1948; Quagliotti, 1971) may be attributed, among other causes, to the differences in copper and manganese uptake connected with climatic conditions. It is known for instance that in dry and warm years copper utilisation by plants is high on dried boggy soils (Só jkow ski, 1271). This problem requires further study, the more so since hardly any data are available on the influence of microclimatic factors on the utilisation and function of microelements.

The author wishes to thank Doc. dr habil. Z. Gumińska of the Botanical Grarden of the Wrociaw University for helpful advice in the experiments and Doc. dr habil. J. Kozlowski of the Institute of Medicinal Herbs Industry in Poznań for Capsicum annuum seeds and a synthetic capsaicin standard.

\section{REFERENCES}

B a lba a S. I., Karavaya M. S., Girgis A. N., 1968. The capsaicin content of Capsicum fruits at different stages of maturity. Lloyda, 31: 273.

Blaim K., Fitulska I., Kasztej Z., 1957. Papryka ważny surowiec przemysłowy. Hod. Rośl. Aklim. i Nasien., 1: 687.

B ork owski B., Gertig H., O ls z a k M., 1957a. Zawartość kapsaicyny i kwasu L-askorbinowego w owocach pieprzowca rocznego (Capsicum annuum L.) w różnych stadiach dojrzewania. Acta Pol. pharm., 14: 283.

Borkowski B., Gertig H., Olszak M., 1957b. Wpływ temperatury suszenia na zawartość kapsaicyny i kwasu L-askorbinowego w owocach pieprzowca rocznego (Capsicum annuum L.). Acta Pol. pharm., 14: 289.

Cholnoky L., 1937. A paprika festkei és A-vitamin hatásuk. Kiserl. Közl., 40: 173 .

Czabajski T., Załęcki R., 1967. Dawkowanie nawozów mineralnych pod pieprzowiec roczny (Capsicum annuum L.). Herba pol., 13: 23.

Gértig H., Olszak M., 1957. Wartość użytkowa niektórych odmian pieprzowca. Acta Pol. pharm., 14: 329.

Golcz L., Kordana S., Załęcki R., 1970. Potrzeby pokarmowe pieprzowca rocznego (Capsicum annuum L.). Herba pol., 2: 107. 
Gomółka B., Szy powski W., 1975. Cwiczenia laboratoryjne i rachunkowe z chemii wody. Politechnika Wrocławska, Wrocław, p. 114.

G u mińska Z., 1966. Uprawa hydroponiczna roślin. Zakład Narodowy im. Ossolińskich, Wrocław, II edition.

H a senbusch W. Ł., 1948. Rukovodstvo po aprobacii selskokhozyaystviennykh kultur. Ovoshch. Kult. i Korm. Korn., 5: 71.

Hermanowicz W., Dożańska W., Sikorowska C., Rolus J., 1967. Fizykochemiczne badania ścieków miejskich i osadów ściekowych. Arkady, Warszawa.

Leete E., Louden M. C. L., 1968. Biosynthesis of capsaicin and dihydrocapsaicin in Capsicum frutescens. J. Amer. Chem. Soc., 90: 6837.

M a rczenko Z., 1968. Kolorymetryczne oznaczanie pierwiastków. WNT, Warszawa.

M i chna M., 1966. Kształtowanie się niektórych składników chemicznych w zależności od dojrzałości owoców u kilku odmian papryki pochodzenia zagranicznego. Rocz. Nauk rol., $91-$ A-2: 421.

Mi c hna M., 1968. Zawartość kapsaicyny i plon suchej masy w owocach pierwszego pokolenia mieszańców różnych odmian Capsicum annuum L. Hod. Rośl. Aklim. i Nasien., 12: 313.

Muszyński J., 1957. Farmakognozja, zarys nauki o surowcach leczniczych. PZWL, Warszawa.

Nowak T. J., 1980a. Effect of foliar fertilization of Capsicum annuum L. together with optimal root fertilization in hydroponic culture on fruit yield and its capsaicin content. Acta agrobot., 33: 000-000.

N o w a k T. J., 1980b. Wpiyw różnych metod uprawy i terminów siewu na ilość i jakość plonu owoców pieprzowca rocznego (Capsicum annuum L.). Biul. warz., 00: 000-000.

Quagliotti L., 1971. Effects of soil moisture and nitrogen level on the pungency of bariers of Capsicum annuum L. Hort. Res., 2: 93.

Skąpski H., 1955. Wplyw odmiany na plon, zawartość witaminy C i kapsaicyny w papryce. Biul. warz., 3: 37.

Śp a l d on E., 1948. Paprika - najbohatši vitaminov. Výziva Lúdu, 3: 84.

Sójkowski Z., 1971. Udział mikroelementów w metabolizmie roślin. PWRiL, Warszawa.

Tyihak E., Gujas A., Juhasz K., 1566. Herstellungsprobleme der Paprika (Capsicum qnuum) Protoalkaloide. Herba Hung., 5: 225.

Ulińska M., 1957. Technika obliczeń statystycznych. PWN, Warszawa.

W aller R. A., Duncan D. B., 1969. A Bayes rule for the symmetric multiple comparisons problem. J. Am. Stat. Assoc., 64: 1484.

\section{Wplyw zwiększonych dawek mikroelementów} w pożywce hydroponicznej na plon owoców

i zawartość w nich kapsaicyny u Capsicum annuนniz L.

Streszczenie

Stosowano hydroponiczną uprawę pieprzowca rocznego w wersji wrocławskiej. W pożywce o składzie podstawowym, zawierającej mikroelementy w ilości po $0,6 \mathrm{mg} / 1$, zwiększano dziesięciokrotnie ilości poszczególnych mikroelementów 
(Cu, B, Mn, Mo i Zn) w różnych kombinacjach. Stwierdzono, że najkorzystniejszą pożywką dla hydroponicznej uprawy pieprzowca, ze względu na plon owoców i wydajność kapsaicyny z rośliny, jest pożywka zawierająca w zwiększonych ilościach miedź i bor lub łącznie oba te pierwiastki, oraz że miedź i mangan w zwiększonych ilościach wpływa korzystnie na akumulację kapsaicyny w suchej masie owoców. Wpływ miedzi i manganu stymulujący zawartość kapsaicyny w owocach obserwowano także gdy w mieszaninie znajdowały się inne pierwiastki w zwiększonych ilościach. Wyjątek stanowiły $\mathrm{Mn}+\mathrm{Mo}+\mathrm{Zn}$ oraz $\mathrm{Mn}+\mathrm{B}+\mathrm{Mo}$, które nie stymulowały zwiększenia zawartości kapsaicyny. Sugeruje się, że proporcje mikroelementów w mieszaninie powinny być ściśle dobrane dla każdego gatunku rośliny i dla określonych warunków agroklimatycznych. 